\title{
PENGEMBANGAN MEDIA GAME INTERAKTIF BILINGUAL BERBASIS PENDIDIKAN KARAKTER DALAM PEMBELAJARAN MATEMATIKA DI SEKOLAH MENENGAH ATAS
}

Oleh:

\author{
${ }^{1)}$ Getut Pramesti, ${ }^{2)}$ Dyah Ratri Aryuna, ${ }^{3)}$ Ponjo Sudjatmiko, ${ }^{4)}$ Mardiyana \\ 1,2,3,4 Universitas Sebelas Maret \\ ${ }^{1}$ getut.uns@gmail.com
}

\begin{abstract}
ABSTRAK
Tujuan dari penelitian ini adalah untuk mengetahui pembelajaran matematika setelah dilakukan pengembangan media game interaktif bilingual berbasis pendidikan karakter pada siswa kelas XII IPS 4 SMAN I EX RSBI Karanganyar. Pengembangan media dilakukan untuk mengetahui apakah terdapat peningkatan penguasaan konsep materi siswa yang ditinjau dari kemampuan kognitif dan karakter siswa. Penelitian ini merupakan penelitian tindakan kelas dengan subjek siswa kelas XII IPS 4 SMAN 1 EX RSBI Karangayar. Dibuat skenario dalam setiap siklus dengan tiga kali pertemuan dengan terlebih dahulu dilakukan pengukuran terhadap kemampuan kognitif dan karakter pada masa pra-siklus. Tiap pertemuan pada masing-masing siklus dilakukan observasi terhadap penguasaan konsep yang diukur dari kemampuan kognitif siswa dan karakter siswa. Hasil penelitian tindakan kelas pada kelas XII IPS 4 SMAN 1 Karanganyar adalah sebagai berikut 1) Pembelajaran matematika pada siswa kelas X SMAN I EX RSBI Karanganyar setelah dilakukan pengembangan media game interaktif bilingual berbasis pendidikan karakter pada pembelajaran Matapelajaran matematika berjalan dengan baik dan lancar. Salah satu indikasi dari terjadinya peningkatan penguasaan konsep materi siswa yang diukur dari kemampuan kognitif siswa, rerata prestasi siswa pada pra-siklus sebesar 53,03, meningkat pada siklus 1 sebesar 82,09 dan kembali meningkat pada siklus 2 sebesar 82,94. 2) Karakter siswa yang diukur antara lain religius, jujur, disiplin, kerja keras, kreatif, mandiri, demokratis, rasa ingin tahu, menghargai prestasi, bersahabat/ komunikatif, senang membaca, peduli sosial, peduli lingkungan, tanggung jawab. Terjadi peningkatan kriteria karakter siswa. Jika pada prasiklus kriteria karakter siswa cukup baik maka pada siklus 1 dan 2 meningkat menjadi baik.
\end{abstract}

Kata Kunci : bilingual, game, interaktif, karakter

\begin{abstract}
The purpose of this study to investigate the learning of mathematics after the development of interactive gaming media bilingual character education based on class XII students of SMAN I EX IPS 4 Karanganyar RSBI. Media development was conducted to determine whether there is a material increase student mastery of concepts in terms of students' cognitive abilities and also the students character. This research is action class with the subjects are students in the class XII IPS 4 of SMAN 1 EX RSBI Karangayar. Scenarios created in each cycle with three meetings with prior measurements on cognitive abilities and character in
\end{abstract}


pre-cycle. Each meeting of each cycle was the observation of the measured concept of astery students' cognitive abilities and character of student. Action research results on class XII IPS 4 SMAN 1 Karanganyar are as follows 1) Learning mathematics in class X SMAN I EX RSBI Karanganyar after the development of interactive gaming media bilingual education based on learning character mathematics lesson goes well and smoothly. One indication of the increasing student mastery of the material being measured concept of cognitive abilities of students, the average achievement of students in pre-cycle was 53,03, an increase in cycle 1 at 82,09 and its increased again in cycle 2 is 82,94. 2) The character of students measured which are religious, honest, disciplined, work hard, creative, independent, democratic, curiosity, recognize excellence, friendship / communicative, happy reading, social care, care for the environment, responsibility. There are an increase in students' character criteria. If the pre-cycle criteria quite well the character of students in cycle 1 and 2 increased to well.

Keywords : bilingual, character, games, interactive

\section{PENDAHULUAN}

Prestasi Matematika Indonesia yang cenderung masih rendah di kancah Internasional perlu ditelaah, mengingat sesungguhnya (berdasarkan hasil penelitian TIMMS yang dilakukan Frederick K. S. Leung pada tahun 2003), jumlah jam pengajaran matematika di Indonesia jauh lebih banyak dibandingkan Malaysia dan Singapura. Dalam satu tahun, siswa kelas 8 di Indonesia rata-rata mendapat 169 jam pelajaran matematika. Sementara di Malaysia hanya mendapat 120 jam dan Singapura 112 jam. Namun sekali lagi kuantitas jam pelajaran Matematika yang relatif lebih banyak tidak menjamin feedback prestasi Matematika yang membanggakan. Dari hasil penelitian (Frederick K.S Leung dalam http://www.topix.com/forum/world/malaysia/TPKMP1F380BEBFJGS) yang dipublikasikan dalam konferensi pers The First Symposium on Realistic Teaching in Mathematics di Majelis Guru Besar ITB menyebutkan, prestasi Indonesia hanya menembus skor rata-rata 411, Indonesia masih kalah apabila dibandingkan dengan Malaysia dan Singapura.

Kondisi "fobia" Matematika ini tak pelak pula pada sekolah dengan status Rintisan Sekolah Bertaraf Internasional (RSBI). RSBI lahir berdasarkan UU no 20 tahun 2003 pasal 50 ayat 3. Depdiknas diharapkan mampu menerapkan standar mutu menuju sekolah bertaraf internasional (SBI) yang memenuhi standar nasional pendidikan serta mempunyai keunggulan yang merujuk pada standar pendidikan salah satu negara anggota Organization for Economic Co-operation Development (OECD) dan/atau negara maju lainnya yang mempunyai keunggulan tertentu dalam bidang pendidikan sehingga memiliki daya saing di forum internasional. Bagaimana tidak, penguasaan konsep Matematika dengan bahasa pengantar Indonesia saja, siswa banyak mengalami kesulitan apalagi pada kelas RSBI/SBI dengan bahasa Inggris sebagai bahasa pengantar. 
Berdasarkan Rekomendasi Dinas Pendidikan dan Kebudayaan Provinsi Jawa Tengah Nomor 193/Dikmen/VI/2008, SMAN 1 Karanganyar mulai membuka program RSBI. Dari mulai membuka program RSBI, peminat kelas tersebut naik setiap tahunnya. Tahun akademik 2009/2010 kelas X berjumlah 304 dengan dibagi menjadi 9 kelas. Berdasarkan observasi penulis dengan pengampu matapelajaran (Mapel) Matematika kelas XII IPS disekolah SMAN I Karanganyar yaitu Bapak Edi Purwanto, M.Pd menyatakan bahwa prestasi akademik pada mata pelajaran Matematika pada tahun akademik 2011/ 2012 cukup rendah karena di bawah nilai kriteria ketuntasan minimal (KKM) sebesar 75. Menurut beliau, rendahnya prestasi siswa kelas IPS dikarenakan beberapa hal antara lain, rendahnya penguasaan konsep materi mapel matematika, kelas yang cenderung "ramai" dan kurangnya motivasi siswa untuk tertarik belajar matematika.

Pengamatan lain dari penulis adalah perlakuan guru terhadap siswanya dalam pembelajaran mapel matematika. Pengantar pembelajaran masih $100 \%$ menggunakan bahasa Indonesia. Padahal status kelas RSBI yang tentunya selayaknya dipersiapkan sedemikian sehingga memenuhi SNP. Tentu permasalahan tersebut perlu mendapat penanganan khusus dan ekstra, mengingat pengelolaan kelas RSBI dalam semua mapel khususnya Matematika berbeda dengan kelas regular. Penanganan ekstra dalam hal ini adalah permasalahan bahasa. Siswa dituntut dapat berbahasa (setidaknya pasif) Inggris, beban "mencerna" pembelajaran Matematika tentu bertambah dengan tuntutan bahasa karena kelas RSBI diwajibkan paling sedikit 30\% menggunakan Bahasa Inggris sebagai bahasa pengantar pembelajaran. Jadi, siswa RSBI selain menghadapi permasalahan dalam penguasaan konsep Matematika ditambah dengan permasalahan bahasa.

Penguasaan konsep berkaitan erat dengan kemampuan kognitif seseorang. Kemampuan kognitif adalah penampilan-penampilan yang dapat diamati sebagai hasil-hasil kegiatan atau proses memperoleh pengetahuan melalui pengalaman sendiri. Menurut Anas Sudijono (2001: 49) ranah kognitif adalah ranah yang mencakup kegiatan mental (otak). Menurut Benjamin S Bloom dkk dalam Anas Sudijono (2001:49-52) taksonomi ranah kognitif meliputi enam jenjang proses berpikir salah satunya adalah pengetahuan (knowledge) adalah kemampuan seseorang untuk mengingat-ingat kembali (recall) atau mengenali kembali tentang nama, istilah, ide, gejala, rumus-rumus dan sebagainya, tanpa mengharapkan kemampuan untuk menggunakannya. Pengetahuan atau ingatan ini merupakan proses berpikir yang paling rendah.

Selain masalah kognitif pada matapelajaran Matematika, isu pendidikan karakter menjadi mengedepan bukan hanya karena menjadi tema peringatan hari Pendidikan Nasional 2010, melainkan lebih disebabkan oleh keprihatinan terhadap praksis pendidikan yang semakin hari semakin tidak jelas arah dan hasilnya. Pendidikan yang dalam UU No. 20 Tahun 2003 tentang SISDIKNAS bertujuan untuk berkembangnya potensi peserta didik agar menjadi manusia yang beriman dan 
bertaqwa kepada Tuhan Yang Maha Esa, berakhlak mulia, sehat, berilmu, cakap, kreatif, mandiri, dan menjadi warga negara yang demokratis serta bertanggung jawab (pasal 3). Hanya dalam kenyataan, justru banyak warga negara yang tidak berakhlak mulia, seperti fenomena maraknya tawuran, korupsi, penyalahgunaan narkoba, hamil di luar nikah, budaya hedonisme, tidak bertanggung jawab, dan banyak kasus lainnya yang justru bertentangan dengan tujuan pendidikan nasional. Beberapa contoh tersebut menindikasikan bahwa pendidikan kita belum mampu membangun karakter bangsa. Praktis pendidikan yang terjadi di kelas-kelas tidak lebih dari latihan-latihan skolastik, seperti mengenal, membandingkan, melatih, dan menghapal, yakni kemampuan kognitif yang sangat sederhana, di tingkat paling rendah (Winarno Surachmad, $d k k .:$ 2003: 114).

Dari latar belakang yang telah diuraikan di atas, memunculkan kebutuhan bentuk pembelajaran yang menyenangkan, dapat meningkatkan secara kognitif siswa pada mata pelajaran Matematika namun juga dapat setidaknya mengenalkan karakterkarakter positif kepada siswa. Salah satu alternatif pembelajaran Matematika yang menawarkan pembelajaran yang interaktif dan juga sekaligus belajar Bahasa Indonesia-Inggris dalam bilingual adalah dengan memanfaatkan game interaktif bilingual (GIB) berbasis pendidikan karakter. Game interaktif bilingual yang dibangun menggunakan macromedia flash sebagai media pembelajaran mapel Matematika. Mengapa dipilih GIB? Menurut observasi penulis, pemanfaatan media game dirasakan perlu untuk menarik minat siswa kelas XII untuk tertarik dan termotivasi belajar Matematika. Penambahan game yang interaktif juga bilingual akan membuat siswa tidak bosan karena siswa diajak untuk aktif bermain edukasi dan secara tidak langsung memperkaya vocabulary siswa tentang perbendaharaan bahasa Indonesia-Inggris. Dari pengalaman ber-"main" Matematika interaktif dan berbahasa Inggris ini, siswa akan semakin mahir baik secara matematis maupun secara praktis berbahasa Inggris. Kombinasi GIB berbasis pendidikan karakter sangat diperlukan, karena pendidikan tidak hanya mengejar aspek kognitif saja dengan ketuntasan kompetensi dan nilai semata namun dibarengi dengan penanaman pendidikan berkarakter (Bab II, Pasal 3, UU RI No 20 Tahun 2003 tentang Sisdiknas).

Perkembangan Teknologi Informasi yang sangat pesat memungkinkan untuk memanfaatkannya dalam bidang Pendidikan, salah satunya dalam mapel Matematika. Diperlukan media bantu berbasis IT karena Matematika merupakan salah satu matapelajaran yang abstrak. Dengan bantuan media dalam bentuk game interaktif diharapkan keabstrakan Matematika menjadi lebih konkrit, selain itu sikap belajar siswa dapat menjadi lebih baik.

Menurut pengampu mapel Matematika, Bapak Edi Purwanto, M.Pd, permasalahan yang kerap muncul dalam pembelajaran Matematika di SMAN 1 Karanganyar kelas XII IPS pada pokok bahasan program linier. Siswa cenderung masih bingung mengkonstruksikan kasus program linier dalam simbol dan notasi matematika. 
Siswa masih mengerjakan kasus-kasus program linier hanya berdasarkan hapalan contoh soal tapi tidak didasarkan pada konsep program linier itu sendiri. Permasalahan lain berkaitan dengan karakter siswa. Siswa XII IPS 4 cenderung masih kurang percaya diri, kurang disiplin dan "ogah-ogahan" belajar matematika. Hal ini dilihat dari pengamatan penulis ketika melakukan observasi awal di SMAN 1 Karanganyar. Masih menurut Bapak Edi Purwanto, M.Pd penguasaan konsep materi program linier siswa kelas XII IPS 4 yang rendah diindikasikan dari rata-rata nilai ulangan yang relatif rendah, masih dibawah 70 .

Atas latar belakang permasalahan di atas, maka penulis berkolaborasi dengan guru mitra pengampu mata pelajaran Matematika pada SMAN I RSBI Karanganyar juga mahasiswa untuk tugas akhirnya untuk mengembangkan media game interaktif bilingual berbasis pendidikan karakter pada pokok bahasan program linier. Pengembangan media game ini dimaksudkan untuk mengetahui proses pembelajaran dengan menggunakan media IT dalam rangka memperbaiki kemampuan kognitif siswa untuk meningkatkan penguasaan konsep siswa dalam pokok bahasan. Selain kemampuan kognitif, akan diukur pula karakter siswa setelah pengembangan media game interaktif.

Berdasarkan permasalahan yang telah diangkat dalam penelitian ini, penulis merumuskan tujuan penelitian adalah untuk mengetahui pembelajaran matematika pada siswa kelas XII SMAN I EX RSBI Karanganyar dengan menggunakan game interaktif bilingual berbasis pendidikan karakter terhadap penguasaan konsep materi siswa ditinjau dari ranah kognitif dan karakter siswa.

\section{METODE}

Pengembangan media game interaktif bilingual berbasis pendidikan karakter didesain dalam penelitian tindakan kelas. Penelitian tindakan kelas yang direncanakan terdiri dari dua siklus Penelitian tindakan kelas dilaksanakan di kelas XII IPS 4 semester ganjil SMAN 1 Karanganyar tahun pelajaran 2013/2014 yang beralamat di Jalan AW Monginsidi No.3 Karanganyar Telp/Fax (0271) 495068. Penelitian dilakukan pada pokok bahasan Program Linier dan diterapkan pada siswa kelas XII IPS 4 SMAN 1 Karanganyar Tahun Pelajaran 2013/2014 berjumlah 35 orang.

Dalam siklus-siklus tersebut terdapat kegiatan antara lain : 1) perencanaan (planning), 2) pelaksanaan tindakan (acting), 3) Observasi (observing) dan 4) Refleksi (reflecting). Rencana tindakan yang akan dilakukan pada setiap siklus seperti Gambar 1. 


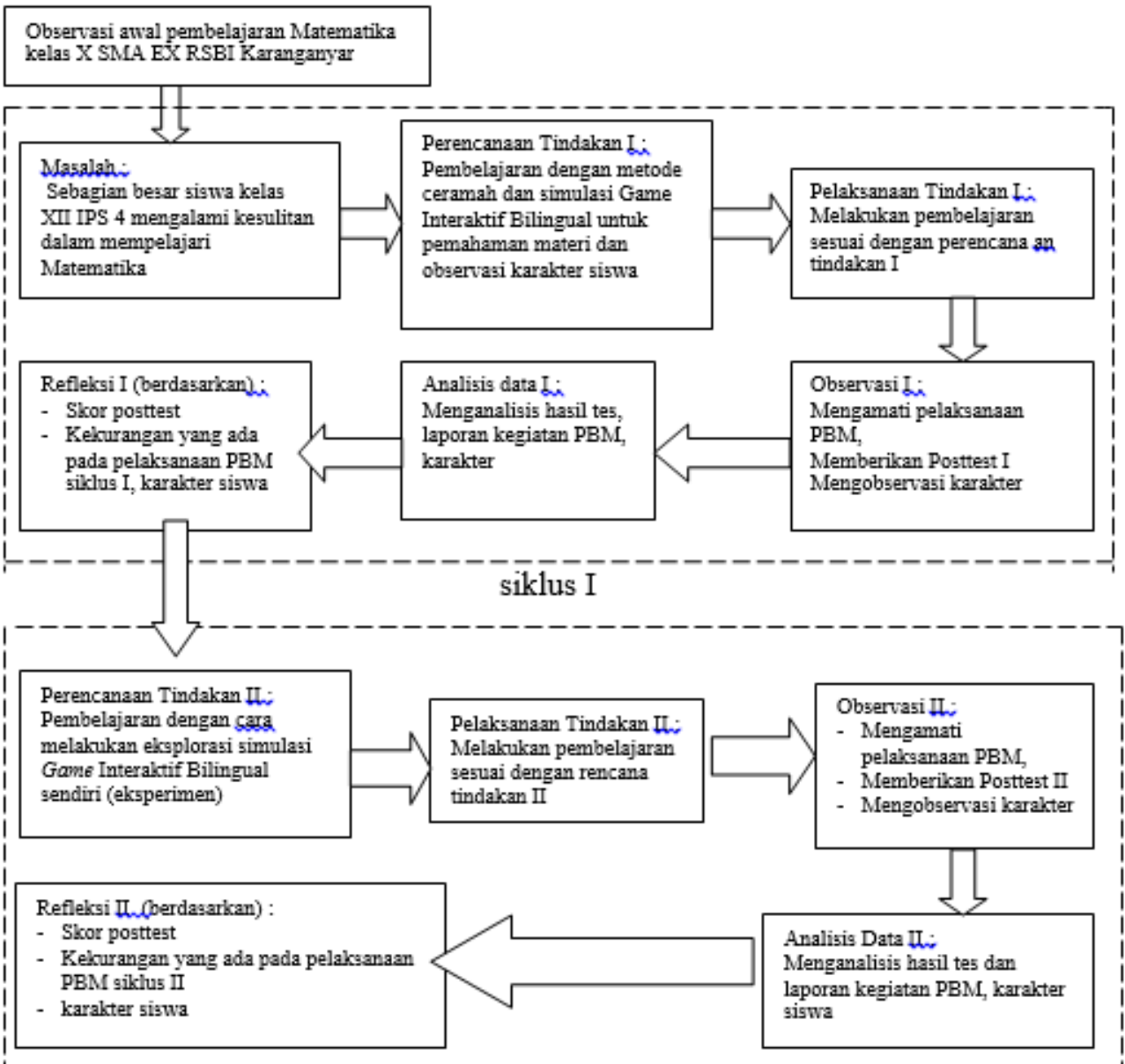

Siklus II

\section{Gambar 1. Siklus PTK}

Semula penelitian direncanakan diberlakukan untuk kelas RSBI, namun karena ada intruksi dari Pemerintah untuk menghapus kelas RSBI mulai tahun akademik 2013/2014 maka penelitian kemudian dilakukan untuk sekolah EX RSBI yaitu pada kelas XII IPS 4 SMAN I EX RSBI program Karanganyar tahun akademik 2013/ 2014. Kelas dengan jumlah siswa 35 orang ini merupakan kelas EX RSBI SMAN I Karanganyar yang beralamat Jalan AW Monginsidi No.3 Karanganyar Telp/Fax (0271) 495068.

Penelitian tindakan kelas dilaksanakan secara bertahap yang secara garis besar dapat dibagi menjadi tiga tahap, yaitu: tahap persiapan, tahap pelaksanaan, dan tahap penyelesaian. Tahap persiapan meliputi koordinasi dengan kepala sekolah dan guru Matematika, observasi, identifikasi masalah pembelajaran, penentuan tindakan, 
penyusunan instrumen penelitian (silabus, RPP, lembar observasi, dan tes), serta observasi lanjutan. Tahap pelaksanaan meliputi kegiatan pengembangan media game interaktif bilingual berbasis pendidikan karakter di Sekolah Menengah Atas, dalam hal ini SMAN 1 Karanganyar. Seperti telah diuraikan pada bagian sebelumnya bahwa kelas RSBI dihapus mulai tahun akademik 2013/2014, hal ini mengakibatkan beberapa pergeseran pelaksanaan rencana dalam tindakan kelas pada penelitian ini. Pergeseran tersebut dikarenakan perubahan kebijakan yang diterapkan SMAN 1 Karanganyar setelah RSBI dihapus diantaranya adalah ; 1) setiap siswa tidak wajib membawa laptop, 2) pembelajarn sudah tidak bilingual. Karena terdapat beberapa pergeseran kebijakan inilah, penelitian ini kemudian menggunakan media game interaktif melalui pengembangan video interaktif pembelajaran berbasis pendidikan karakter. Tahap penyelesaian meliputi analisis data hasil pelaksanaan tindakan dan penyusunan laporan penelitian.

Teknik analisis yang dilakukan dalam penelitian tindakan kelas XII IPS 4 SMAN 1 Karanganyar adalah deskriptif. Teknik tersebut dilakukan karena sebagian besar data yang dikumpulkan dalam penelitian berupa uraian deskriptif tentang perkembangan proses, yakni peningkatan kemampuan kognitif siswa dan juga karakter siswa.

Kemampuan kognitif siswa di kelas XII IPS 4 SMAN 1 Karanganyar diperoleh dari tes bentuk uraian. Hasil tes dianalisis menggunakan rubrik penilaian kemampuan komunikasi matematis. Untuk memudahkan analisis, hasil penskoran yang diperoleh kemudian dipersentase dengan rumus :

Prosentaseskor tes $(\mathrm{x})=\frac{\sum \text { skor }}{\text { skor maksimal }} \times 100 \%$

dengan kriteria hasil penskoran seperti Tabel 1.

Tabel 1

Kriteria Prosentase

\begin{tabular}{|c|c|}
\hline Persentase yang diperoleh $(x)$ & Kriteria \\
\hline $0 \% \leq x \leq 33,32 \%$ & Rendah \\
\hline $33,33 \% \leq x \leq 66,65 \%$ & Sedang \\
\hline $66,66 \% \leq x \leq 100 \%$ & Tinggi \\
\hline
\end{tabular}

(Rofiah, 2010: 46)

Analisis hasil observasi karakter siswa akan dianalisis, yaitu untuk jawaban "Ya" akan diberi skor 1 dan jawaban "Tidak" diberi skor 0. Selanjutnya dihitung prosentase hasil observasi karakter siswa setiap siklus dapat diketahui dengan rumus :

$$
\mathrm{P}=\frac{\text { skor capaian }}{\text { skor maksimal }} \times 100 \%
$$


dengan $\mathrm{P}$ merupakan prosentase karakter siswa, skor capaian adalah jumlah skor amatan dalam satu siklus dan skor maksimal merupakan jumlah skor maksimal amatan dalam satu siklus.

Dalam penelitian tindakan kelas XII IPS 4 menggunakan triangulasi sumber sehingga prosentase karakter siswa setiap siklus adalah rata-rata persentase hasil observasi dari observer. Selanjutnya persentase karakter siswa tersebut dikriteriakan sesuai dengan kualifikasi hasil persentase observasi seperti Tabel 2.

Tabel 2

Pedoman Kualifikasi

\begin{tabular}{|c|c|}
\hline $\begin{array}{c}\text { Persentase yang diperoleh } \\
(p)\end{array}$ & Kriteria \\
\hline $0 \% \leq \mathrm{P} \leq 25 \%$ & Kurang baik \\
\hline $26 \% \leq \mathrm{P} \leq 50 \%$ & Cukup baik \\
\hline $51 \% \leq \mathrm{P} \leq 75 \%$ & Baik \\
\hline $76 \% \leq \mathrm{P} \leq 100 \%$ & Sangat baik \\
\hline
\end{tabular}

(Barbara dan Hariastuti, 2011: 9)

\section{HASIL DAN PEMBAHASAN}

Kondisi awal kelas XII IPS 4 SMAN 1 Karanganyar sebelum dikenakan pembelajaran dengan memanfaatkan media game interaktif bilingual berbasis pendidikan karakter dapat diobservasi penulis antara lain sebagai berikut :

1) Kebanyakan siswa telat masuk ruang kelas ketika masuk matapelajaran Matematika, mereka cenderung mengabaikan jam masuk. Terlihat beberapa dari siswa yang sedang makan-makan di koridor kelas. Jika pun ada beberapa siswa yang masuk kelas, siswa terkesan masih malas untuk memulai mapel matematika. Kebanyakan dari siswa ngobrol dengan teman-temannya.

2) Ketika akan diadakan tes pra-siklus, banyak siswa yang protes kepada guru, kaget dan suasana menjadi bising karena siswa merasa belum siap untuk mengerjakan tes, meskipun tes pra siklus sebenarnya notabene untuk mengetahui kemampuan awal siswa. Dengan kata lain materi yang di tes-kan sudah pernah siswa peroleh pada jenjang sebelumnya, namun yang terjadi hampir seluruh siswa mengerjakan tes pra siklus secara bersama-sama dengan teman sebangkunya.

3) Saat tes pra siklus, kelas relatif ramai, tidak ada siswa yang mengerjakan sendiri, alias semua mengerjakan secara bersama-sama. Ini mengindikasikan selain siswa memang tidak mempunyai kemampuan awal yang cukup kompeten juga rasa percaya diri siswa yang bisa dikatakan masih rendah, sehingga saat mengerjakan mereka tidak "PD" mengerjakan dengan pengetahuan mereka sendiri. 
Dari hasil tes pra siklus yang dikenakan pada kelas XII IPS 4 SMAN 1 Karanganyar pada 23 Agustus 2013 dapat diketahui bahwa prosentase kemampuan kognitif pada pra-siklus dengan kriteria tinggi sebesar $42,42 \%$ sedangkan kriteria sedang sebesar $54,55 \%$ sisanya siswa dengan kriteria rendah sebesar 3,03\%. Rata-rata nilai siswa sebesar 53,03.

Selain penguasaan konsep materi siswa yang diukur dari kemampuan kognitif, diobservasi pula karakter siswa kelas XII IPS 4 SMAN 1 Karanganyar dengan cara mengamati kondisi siswa saat pembelajaran matapelajaran Matematika berlangsung. Validasi data dari karakter siswa menggunakan triangulasi sumber, yaitu dengan membandingkan hasil observasi dari 3 observer yang berbeda. Data yang diperoleh dikatakan valid jika menghasilkan hasil yang sama. Apabila data tidak valid maka diambil kesimpulan observasi dari hasil pengamatan dari dua observer yang sama. Berdasarkan total skor capaian hasil obsevasi karakter siswa kelas XII IPS 4 SMAN 1 Karanganyar pada pra-siklus adalah 10 poin dari 27 poin. Dari skor maksimum sebesar 27 poin, prosentase skor capaian karakter siswa sebelum pemanfaatan media GIB adalah sebagai berikut :

$$
\begin{aligned}
P & =\frac{\text { skor capaian }}{\text { skor maksimal }} \times 100 \% \\
& =\frac{10}{27} \times 100 \% \\
& =37,04 \%
\end{aligned}
$$

Hasil observasi awal menunjukkan bahwa karakter siswa yang diukur dari 15 aspek dengan 27 poin observasi adalah sebesar 37,04\% dan termasuk pada kriteria cukup baik. Dari hasil tes pra-siklus juga dapat dikatakan bahwa siswa masih belum bisa optimal berprestasi dalam matapelajaran Matematika karena lebih dari 50\% kemampuan kognitif siswa masuk dalam kriteria sedang. Hasil lapangan ini diperkuat dengan hasil observasi karakter siswa yang hanya masuk pada kriteria cukup baik. Dari analisis ini, nampak kemungkinan keeratan hubungan antara kemampuan kognitif dan karakter siswa.

Hasil pra-siklus menguatkan dugaan sementara penulis bahwa dengan media berbasis pendidikan karakter akan meningkatkan kemampuan kognitif siswa dalam matapelajaran Matematika dan tentunya karakter siswa itu sendiri. Dengan memanfaatkan media game interaktif bilingual berbasis pendidikan karakter, diharapkan, pada mulanya siswa akan dipaksa untuk belajar mandiri dengan membuka media pembelajaran di rumah atau dimanapuan siswa, karena media bersifat portabel. Dengan belajar mandiri diharapkan karakter-karakter positif siswa akan tergali seperti religius, jujur, disiplin, kerja keras, kerja cerdas, kreatif, 
demokratis, rasa ingin tahu, menghargai prestasi, bersahabat/ komunikatif, senang membaca, peduli sosial, peduli lingkungan dan bertanggungjawab.

Siklus 1 dilaksanakan dalam tiga kali pertemuan. Perencanaan tindakan untuk siklus 1 meliputi:

1. Penyusunan skenario pembelajaran,

2. Pembuatan media pembelajaran,

3. Penyusunan bahan ajar, lembar kerja, soal kuis dan tes siklus 1

4. Penyusunan lembar observasi karakter siswa

Untuk lembar observasi karakter siswa disusun untuk mengetahui karakter siswa kelas XII IPS 4, disusun dari pra-siklus, siklus 1 dan siklus 2. Instrumen dikembangkan sama berdasarkan definisi pendidikan karakter menurut Ki Hajar Dewantoro dalam Haryanto (2012:4). Pendidikan karakter adalah upaya yang terencana untuk menjadikan peserta didik mengenal, peduli dan menginternalisasi nilai-nilai sehingga peserta didik berperilaku sebagai insan kamil, dimana tujuan pendidikan karakter adalah meningkatkan mutu penyelenggaraan dan hasil pendidikan di sekolah melalui pembentukan karakter peserta didik secara utuh, terpadu, dan seimbang, sesuai standar kompetensi lulusan. Adapun nilai-nilai yang perlu dihayati dan diamalkan oleh guru saat mengajarkan mata pelajaran di sekolah adalah: religius, jujur, toleran, disiplin, kerja keras, kerja cerdas, kreatif, mandiri, demokratis, rasa ingin tahu, semangat kebangsaan, cinta tanah air, menghargai prestasi, bersahabat/komunikatif, cinta damai, senang membaca, peduli sosial, peduli lingkungan, dan tanggung jawab.

Pelaksanaan tindakan pertama terdiri dari tiga pertemuan, yaitu pada 30 Agustus 2013, 2 September 2013 dan 6 September di kelas XII IPS 4 Karanganyar tahun pelajaran 2013/2014. Siklus 1 terdiri dari dua kali pertemuan untuk tindakan dan satu kali pertemuan untuk tes siklus 1 . Materi pada pertemuan siklus 1 mengenai sistem pertidaksamaan linier dua variabel dan merancang model Matematika yang berkaitan dengan program linier.

Pada pertemuan pertama, guru membuka pelajaran Matematika dengan mengucapkan salam dan kemudian mereview materi sebelumnya tentang integral. Selanjutnya guru mengenalkan tentang kompetensi selanjutnya yaitu program linier. Guru menerangkan tujuan pembelajaran materi program linier. Pada pertemuan pertama sebelum guru memperagakan pembelajaran menggunakan media, terlebih dahulu guru mengenalkan kemampuan awal yang diperlukan dalam pembelajaran program linier. Peragaan pembelajaran menggunakan media berlangsung lancar dan menarik. Siswa cenderung antusias mengikuti pembelajaran. Sesekali jika ada bagian media yang lucu, siswa tertawa dan mengikuti pembelajaran dengan rileks tetapi serius menyimak. Setelah pembelajaran dengan menggunakan media selesai, 30 menit terakhir diisi guru untuk memberikan latihan. Selama 15 menit siswa mengerjakan, 15 menit selanjutnya siswa mengerjakan di depan dan ditulis pada 
papan tulis. Beberapa siswa nampak masih salah mengerjakan dalam menentukan Himpunan penyelesaian dengan menggunakan gambar. Jika penentuan himpunan penyelesaian dengan himpunan, siswa cenderung tidak mengalami kebingungan, namun begitu himpunan tersebut ditransformasikan ke dalam bentuk gambar, kadang siswa masih salah menginterpretasikan.

Sebelum guru menutup kelas pelajaran matematika, guru berpesan kepada siswa untuk membuka cd pembelajaran part 3 dan 4 dan akan langsung di review pada pertemuan selanjutnya yaitu hari Senin, 2 September 2013. Siswa mengiyakan dan kelas Matematika-pun selesai. Pada pertemuan pertama ini, observasi terhadap karakter siswa mulai dilakukan. Siswa kelas XII IPS 4 terlihat mulai tertib mengikuti pembelajaran, meskipun masih ada beberapa siswa yang kadang malas atau mengobrol sendiri namun secara keseluruhan siswa antusias mengikuti pelajaran. Penampilan siswa juga rapi, mereka menggunakan seragam sesuai dengan jadwal harinya. Ruangan kelas di bagian belakang kelas nampak masih berantakan, terlihat sapu, alat-alat kebersihan, cermin dan helm siswa tergeletak tanpa ditata di pojok ruangan.

Pertemuan kedua membicarakan tentang model matematika. Seperti biasanya kelas matematika dibuka dengan salam oleh guru, siswa pun menjawab dengan kompak. Guru kemudian menanyakan apakah siswa sudah membuka cd pembelajaran part 3 dan 4. Guru pun ingin mengklarifikasi jawaban siswa dengan selanjutnya memberikan pertanyaan. Karena masih banyak siswa yang bingung maka guru selanjutnya kembali menggunakan media pembelajaran part 3, 4 dan 5. Siswa nampak antusias mengikuti pembelajaran meskipun sebenarnya isi dari media pembelajaran sudah mereka punyai. Setelah pembelajaran dengan menggunakan media selesai, 30 menit terakhir diisi guru untuk memberikan latihan. Selama 15 menit siswa mengerjakan, 15 menit selanjutnya siswa mengerjakan di depan dan ditulis pada papan tulis. Pemantauan penulis, nampak bahwa siswa masih bingung mendefinisikan variabel-variabel dalam soal cerita menjadi notasi-notasi matematika. Mereka cenderung hanya terkesan hapalan kasus matematika, sehingga ketika kasus dimodifikasi siswa masih terkesan bingung. Guru kemudian mengklarifikasi kebingungan siswa dengan penjelasan yang mudah dipahami dan bahasa yang sederhana sehingga mudah dimengerti oleh siswa.

Pertemuan ketiga adalah waktu siswa untuk mengerjakan tes siklus 1 . Tes siklus 1 diadakan pada 45 menit terakhir. Adapun 45 pertama diisi guru untuk me-refresh pengetahuan siswa dengan memberikan pertanyaan-pertanyaan kepada siswa dan meminta siswa untuk mengerjakan soal kemudian ditulis di papan tulis. 45 menit berakhir, saatnya tes siklus diadakan. Tes siklus 1 diadakan dalam waktu 45 menit. Suasana kelas cenderung lebih kondusif dibandingkan saat tes pra siklus. Siswa tertib mengikuti tes, kelas kondusif. Siswa terlihat serius mengerjakan, meskipun terlihat beberapa siswa tidak tenang mengerjakan namun secara keseluruhan siswa lebih siap mengerjakan tes siklus 1 dibandingkan saat pra-siklus. 
Pada proses pembelajaran yang berlangsung dilakukan penilaian terhadap penguasaan konsep materi yang diukur dari kemampuan kognitif siswa kelas XII IPS 4 SMAN 1 Karanganyar siklus 1 diketahui bahwa prosentase kemampuan kognitif pada siklus 1 dengan kriteria tinggi sebesar 96,97\% sedangkan kriteria sedang sebesar 3,03\%. Rata-rata nilai siswa sebesar 82,09. Jika menelaah lagi pada hasil pra-siklus terjadi peningkatan rerata kemampuan kognitif pra siklus sebesar 53,03 sedangkan pada siklus 1 sebesar 82,09.

Selain penguasaan konsep materi siswa yang diukur dari kemampuan kognitif, diobservasi pula karakter siswa kelas XII IPS 4 SMAN 1 Karanganyar dengan cara mengamati kondisi siswa saat pembelajaran matapelajaran Matematika berlangsung. Validasi data dari karakter siswa menggunakan triangulasi sumber, yaitu dengan membandingkan hasil observasi dari 3 observer yang berbeda. Data yang diperoleh dikatakan valid jika menghasilkan hasil yang sama. Apabila data tidak valid maka diambil kesimpulan observasi dari hasil pengamatan dari dua observer yang sama. Berdasarkan total skor capaian hasil obsevasi karakter siswa kelas XII IPS 4 SMAN 1 Karanganyar pada siklus 1 adalah 17 poin dari 26 poin. Prosentase skor capaian karakter siswa pada siklus 1 dengan pembelajaran memanfaatkan media GIB adalah sebagai berikut :

$$
\begin{aligned}
P & =\frac{\text { skor capaian }}{\text { skor maksimal }} \times 100 \% \\
& =\frac{17}{26} \times 100 \% \\
& =65,38 \%
\end{aligned}
$$

Hasil siklus 1 terjadi peningkatan kriteria karakter siswa, jika pada pra-siklus kriterianya adalah cukup baik maka pada siklus 1 menjadi baik. Dengan pemanfaan media pembelajaran GIB, karakter siswa menjadi lebih baik dari cukup menjadi baik. Tentunya hal ini patut mendapat perhatian bahwa penggunaan media dapat memancing, menstimulus karakter positif siswa kearah yang lebih baik.

Siklus 2 dilaksanakan dalam tiga kali pertemuan. Perencanaan tindakan untuk siklus 2 meliputi:

1. Penyusunan skenario pembelajaran,

2. Pembuatan media pembelajaran,

3. Penyusunan bahan ajar, lembar kerja, soal kuis dan tes siklus 2

4. Penyusunan lembar observasi karakter siswa

Pelaksanaan tindakan pertama terdiri dari tiga pertemuan, yaitu pada 9 September 2013, 13 September 2013 dan 16 September di kelas XII IPS 4 Karanganyar tahun pelajaran 2013/2014. Siklus 2 terdiri dari dua kali pertemuan untuk tindakan dan 
satu kali pertemuan untuk tes siklus 2. Materi pada pertemuan siklus 2 mengenai metode uji titik sudut dan metode garis selidik.

Pada pertemuan pertama, guru membuka pelajaran Matematika dengan mengucapkan salam. Guru me-review apakah siswa sudah mempelajari video part 6, kemudian klarifikasi materi dari guru dengan menggunakan video part 6 . Dilanjutkan penyampaian materi : metode Uji Titik Sudut, guru dapat menggunakan CD Suplemen berupa media mandiri apabila dirasa perlu. Selanjutnya guru mengenalkan tentang kompetensi selanjutnya yaitu pertidaksamaan dua variabel. Guru menerangkan tujuan pembelajaran materi metode uji titik sudut. Peragaan pembelajaran menggunakan media berlangsung lancar dan menarik. Siswa cenderung antusias mengikuti pembelajaran. Sama seperti pada siklus 1, nampak bahwa siswa memang sudah membuka media sebelumnya. Hal ini terlihat dari kesiapan siswa ketika guru menayangkan media.

Sesekali jika ada bagian media yang lucu, siswa tertawa dan mengikuti pembelajaran dengan rileks tetapi serius menyimak. Setelah pembelajaran dengan menggunakan media selesai, 30 menit terakhir diisi guru untuk memberikan latihan. Selama 15 menit siswa mengerjakan, 15 menit selanjutnya siswa mengerjakan di depan dan ditulis pada papan tulis. Jika ada pertanyaan guru akan kembali memutar media, kemudian mengklarifikasi bagian konsep materi yang masih misinterpretasi oleh siswa.

Pertemuan kedua membicarakan tentang penyelesaian pertidaksamaan dengan menggunakan metode garis selidik. Seperti biasanya kelas matematika dibuka dengan salam oleh guru, siswa pun menjawab dengan kompak. Guru kemudian menanyakan apakah siswa sudah membuka cd pembelajaran part 7. Guru pun ingin mengklarifikasi jawaban siswa dengan selanjutnya memberikan pertanyaan. Karena masih banyak siswa yang bingung maka guru selanjutnya kembali menggunakan media pembelajaran part 7 dilanjutkan dengan part 8. Siswa nampak antusias mengikuti pembelajaran meskipun sebenarnya isi dari media pembelajaran sudah mereka punyai. Setelah pembelajaran dengan menggunakan media selesai, 30 menit terakhir diisi guru untuk memberikan latihan. Selama 15 menit siswa mengerjakan, 15 menit selanjutnya siswa mengerjakan di depan dan ditulis pada papan tulis.

Selain menggunakan media, guru kemudian memberikan contoh-contoh kasus yang serupa, hal ini dilakukan untuk memastikan siswa benar-benar memahami konsep materi penentuan pertidaksamaan dengan menggunakan metode selidik. Selain itu, guru juga membandingkan algoritma penentuan penyelesaian dengan menggunakan uji titik sudut agar siswa dapat menimbang dan memutuskan metode mana yang paling baik dapat digunakan untuk mantauan penulis, nampak bahwa siswa masih bingung mendefinisikan variabel-variabel dalam soal cerita menjadi notasi-notasi matematika. Mereka cenderung hanya terkesan hapalan kasus matematika, sehingga ketika kasus dimodifikasi siswa masih terkesan bingung. Guru kemudian 
mengklarifikasi kebingungan siswa dengan penjelasan yang mudah dipahami dan bahasa yang sederhana sehingga mudah dimengerti oleh siswa.

Pertemuan ketiga adalah waktu siswa untuk mengerjakan tes siklus 2 . Tes siklus 2diadakan pada 45 menit terakhir. Adapun 45 pertama diisi guru untuk me-refresh pengetahuan siswa dengan memberikan pertanyaan-pertanyaan kepada siswa dan meminta siswa untuk mengerjakan soal kemudian ditulis di papan tulis. 45 menit berakhir, saatnya tes siklus diadakan. Tes siklus 2 diadakan dalam waktu 45 menit. Seperti pada tes siklus 1, suasana kelas pada tes siklus 2 juga nampak sudah kondusif. Siswa terlihat tertib mengikuti tes, hanya beberapa yang terlihat bingung mengerjakan soal namun secara keseluruhan kondisi kelas dapat dikatakan baik.

Hasil tes siklus 2 setelah menggunakan media GIB dan berdasarkan dapat diketahui bahwa prosentase kemampuan kognitif pada siklus 2 dengan kriteria tinggi sebesar $80 \%$ sedangkan kriteria sedang sebesar 20\%. Rata-rata nilai siswa sebesar 82,94.

Berdasarkan total skor capaian hasil obsevasi karakter siswa kelas XII IPS 4 SMAN 1 Karanganyar pada siklus 2 adalah 17 poin dari 26 poin. Prosentase skor capaian karakter siswa pada siklus 2 dengan pembelajaran memanfaatkan media GIB adalah sebagai berikut :

$$
\begin{aligned}
P & =\frac{\text { skor capaian }}{\text { skor maksimal }} \times 100 \% \\
& =\frac{17}{26} \times 100 \% \\
& =65,38 \%
\end{aligned}
$$

Secara keseluruhan pengukuran kemampuan kognitif dan karakter siswa ditabulasikan pada Tabel 3.

Tabel 3

Pengukuran kemampuan kognitif dan karakter

\begin{tabular}{|c|c|c|c|c|}
\cline { 2 - 5 } \multicolumn{1}{c|}{} & $\begin{array}{c}\text { Kemampuan } \\
\text { kognitif }\end{array}$ & $\begin{array}{c}\text { Rerata } \\
\text { Kemampuan } \\
\text { kognitif }\end{array}$ & $\begin{array}{c}\text { Prosentase } \\
\text { karakter }\end{array}$ & $\begin{array}{c}\text { Kriteria } \\
\text { karakter }\end{array}$ \\
\hline Pra-siklus & $\mathrm{T}=42,42 \%$ & 53,03 & $37,04 \%$ & Cukup baik \\
& $\mathrm{S}=54,55 \%$ & & & \\
\hline Siklus 1 & $\mathrm{T}=3,03 \%$ & & & Baik \\
& $\mathrm{S}=3,03 \%$ & 82,09 & $65,38 \%$ & \\
\hline Siklus 2 & $\mathrm{R}=0 \%$ & & & Baik \\
& $\mathrm{T}=80 \%$ & 82,94 & $65,38 \%$ & \\
& $\mathrm{~S}=0 \%$ & & & \\
\hline
\end{tabular}




\section{Inffinnitefy}

Keterangan :

Kolom kemampuan kognitif T:Tinggi, S: Sedang dan R: Rendah

Secara visulisasi, perkembangan kemampuan kognitif siswa seperti Gambar 2.

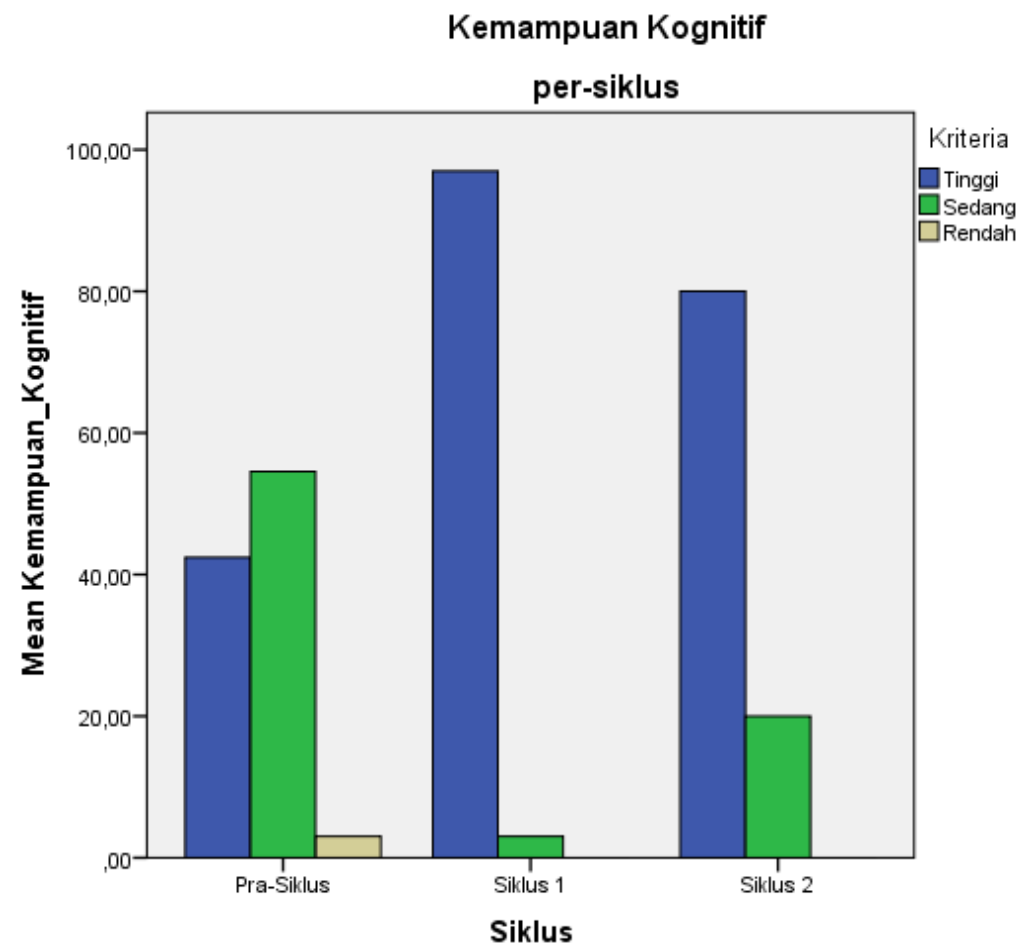

Gambar 2 Kemampuan kognitif siswa

Dari Gambar 2 merupakan visualisasi kemampuan kognitif siswa pada tiap siklus. Batang berwarna biru merupakan kemampuan kognitif siswa dengan kriteria tinggi, batang hijau merupakan kemampuan kognitif siswa dengan kriteria sedang dan batang coklat merupakan kemampuan kognitif siswa dengan kriteria rendah. Apabila diperhatikan gambar 2, nampak bahwa kemampuan kognitif siswa kriteria rendah hanya muncul pada pra-siklus.

Adapun karakter siswa, secara visulisasi dapat seperti Gambar 3. 


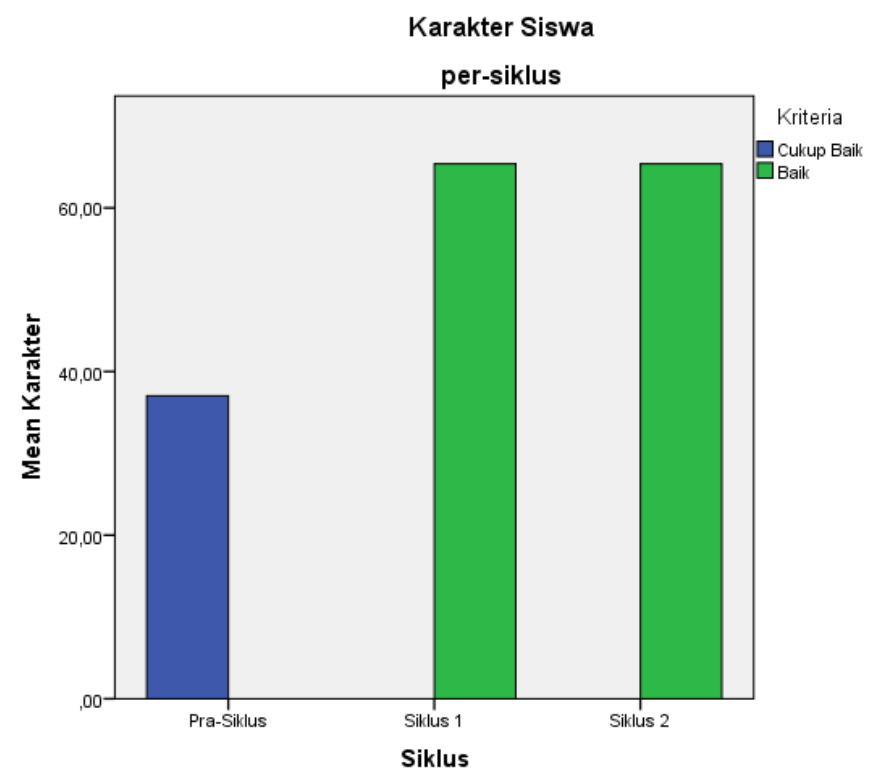

Gambar 3 Karakter siswa

Dari Gambar 3 nampak bahwa karakter siswa pada pra siklus mempunyai kriteria cukup baik, status ini meningkat pada siklus 1 dan siklus 2 dengan kriteria baik.

\section{KESIMPULAN}

Dari hasil tindakan penelitian kelas yang telah dilaksanakan di SMAN 1 Karanganyar kelas XII IPS 4 dapat disimpulkan sebagai berikut :

1. Pengembangan media game interaktif berbasis pendidikan karakter pada proses pembelajaran matematika siswa kelas X SMAN I EX RSBI Karanganyar berjalan dengan baik dan lancar. Hal ini terindikasi dari terjadinya peningkatan penguasaan konsep materi siswa yang diukur dari kemampuan kognitif siswa. Rerata kemampuan kognitif siswa pada pra-siklus sebesar 53,03, pada siklus 1 sebesar 82,09 dan pada siklus 2 sebesar 82,94.

2. Pengembangan media game interaktif berbasis pendidikan karakter pada proses pembelajaran matematika siswa kelas X SMAN I EX RSBI Karanganyar dapat meningkatkan karakter positif pada siswa. Karakter siswa yang diukur antara lain religius, jujur, disiplin, kerja keras, kreatif, mandiri, demokratis, rasa ingin tahu, menghargai prestasi, bersahabat/ komunikatif, senang membaca, peduli sosial, peduli lingkungan, tanggung jawab. Hal ini terindikasi dari terjadi peningkatan kriteria karakter siswa. Jika pada pra-siklus kriteria karakter siswa adalah cukup baik maka pada siklus 1 dan 2 meningkat menjadi baik. 


\section{DAFTAR PUSTAKA}

Anas Sudijono, 2001. Pengantar Evaluasi Pendidikan. Jakarta: RajaGrafindo Persada.

Barbara, F.Y. dan Hariastuti, R.T. (2011). Meningkatkan Partisipasi Siswa Mengikuti Layanan Informasi Melalui Penggunaan Media Permainan. Jurnal Psikologi Pendidikan dan Bimbingan, 12 (2), 1-13. Diperoleh 27 Februari 2013, dari http://ppb.jurnal.unesa.ac.id/bank/jurnal/11._Artikel_ Fely_dan_Retno_T.pdf

Haryanto. 2012. PENDIDIKAN KARAKTER MENURUT KI HADJAR DEWANTARA.

http://www.mandikdasmen.depdiknas.go.id/web/pages/urgensi.html

Rofiah, A. (2010). Peningkatan Kemampuan Komunikasi Matematika Pada Siswa Kelas VII SMP N 2 Depok Yogyakarta Dalam Pembelajaran Matematika Melalui Pendekatan Inkuiri. Skripsi. Universitas Negeri Yogyakarta, Yogyakarta.

TIMMS. (2004). Highlihts from The Trends in International Mathematics and Science Study (TIMMSS). Washington, D.C: National Center for Statistics (NCES), Institute of Education Sciences, U.S. Departement of Education.

Winarno Surakhmad, dkk. (2003). Mengurai Benang Kusut Pendidikan. Jakarta: Transformasi.

http://www.topix.com/forum/world/malaysia/TPKMP1F380BEBFJGS (diakses 04 April 2011) 